\title{
Study of solid biomass combustion modeling using OpenFoam
}

\author{
Gabriel García ${ }^{1 *}$, Jorge Chacón', Yesid Rueda', David Fuentes', Jairo Martínez²
}

`Grupo de Investigación en Energía y Medio Ambiente (GIEMA), Escuela de Ingeniería Mecánica, Universidad Industrial de Santander

${ }^{2}$ Centro Nacional de Investigaciones para la Agroindustrialización de Especies Vegetales

Aromáticas y Medicinales Tropicales (CENIVAM), Escuela de Química, Universidad Industrial de Santander.

*Autor para correspondencia / Corresponding Author: g.garciasanchez@yahoo.es W

\section{Estudio de modelado de la combustión de biomasa sólida usando OpenFoam}

\begin{abstract}
Biomass is an important renewable energy source that has great potential as a substitute for fossil fuels in the short and medium-term, which has led to the development of various methods for its energy conversion, of which combustion is the most widely used. This process has several environmental advantages compared to traditional energy sources, however, there is still a long way to go in terms of process efficiency and emission reduction. In this context, CFD computational models are a powerful tool that enables the study and improvement the performance of combustion systems in a safe, fast and economical way, compared to experimental studies. OpenFoam is one of the most important CFD software currently available, yet there are few works that use it to simulate the combustion of solid biomass. In this work, an application of the software in modeling of a biomass boiler fueled by grape marc is reported, this model allows for the prediction of important parameters like $\mathrm{CO}, \mathrm{H} 2 \mathrm{O}$ and velocity fields in a $2 \mathrm{D}$ domain.
\end{abstract}

Licencia Creative Commons Atribución-NoComercial 4.0 (1) (

Editado por / Edited by: Dennis Cazar

Recibido / Received: $17 / 11 / 2020$

Aceptado / Accepted: 16/04/2021

Publicado en línea / Published online: $15 / 12 / 2021$
Keywords: Solid Biomass, Combustion, Simulation, Modeling, OpenFoam.

\section{Resumen}

La biomasa es una importante fuente de energía renovable que tiene un gran potencial como sustituta de los combustibles fósiles en el corto y mediano plazo, lo cual ha llevado al desarrollo de varios métodos para su conversión energética, de los cuales la combustión es el más utilizado. Este proceso, llevado a cabo con biomasa, tiene varias ventajas medioambientales comparadas con el mismo al utilizar fuentes de energía tradicionales, sin embargo, todavía hay un camino largo por recorrer en términos de mejora de la eficiencia del proceso y la reducción de emisiones. En este contexto, los modelos computacionales CFD son una herramienta poderosa que permite estudiar y mejorar el desempeño de sistemas de combustión de una manera segura, rápida y económica, en comparación con estudios experimentales. OpenFoam es uno de los softwares CFD más importantes disponibles en la actualidad, no obstante, hay pocos trabajos que lo utilicen para simular la combustión de biomasa sólida. En este trabajo se reporta una aplicación de dicho software en el modelado de la combustión en una caldera alimentada con 
orujo de uva, este modelo permite predecir parámetros importantes como el campo de velocidades y las emisiones de $\mathrm{CO}$ y $\mathrm{H} 2 \mathrm{O}$ en un dominio $2 \mathrm{D}$.

Palabras clave: Biomasa sólida, Combustión, Simulación, Modelado, OpenFoam.

\section{INTRODUCTION}

To overcome the serious environmental problems of global warming and poor air quality, it is necessary to develop clean energy sources and reduce society's energy consumption. Studies have been carried out around the world in order to find and improve renewable energy sources that can replace fossil fuels. Biomass is one of the most important; it is considered the most promising energy source to mitigate greenhouse emissions in the short and medium-term [1]. The use of biomass-derived power has increased during the last few decades [2], becoming the fourth largest energy source worldwide, after coal, oil, and natural gas [3] [4] [5]. However, there remain challenges associated with optimizing and applying biomass technologies which make biomass energy conversion seemingly too inefficient to be an environmentally and commercially viable alternative to traditional finite fuels [2].

Over time, various processes have been developed for the transformation of biomass into energy, framed within thermochemical, biochemical and chemical conversion routes. Of these, combustion is the most used as it is the most suitable from the economic point of view [6] [1]. Nevertheless, there remain problems in current biomass combustion furnaces, such as slagging, instability of heat load, and low thermal efficiency [7] [8]. These present a necessity in terms of research to improve the performance of these devices and to reduce pollutants, as the increase in efficiency leads to a significant decrease in emissions and fuel consumption; analysis has shown that a 1\% increase in the efficiency of biomass power plants causes a 3\% reduction in their $\mathrm{CO} 2$ emissions [1]. Another area of improvement needed in the research is the biomass characterization in terms of its physico-chemical properties, which is imperative to understanding biomass combustion. Traditionally the most commonly used solid is wood but, in order to improve energy utilization, an increase of the use of other types of biomass is expected, including a diversity of agricultural residues and biogenic waste [9]. These will require the study of their properties and transformation processes to achieve maximum energy performance.

Computational models are a valuable tool to improve the performance of biomass combustion systems since - the design and operating conditions of these systems can be improved without incurring the economic and environmental costs of the experimental studies[10] [11]. This has motivated the development of Computational fluid dynamics (CFD) models in recent decades. A full review of this topic is presented in the works of Dernbecher et al. [6], Karim and Naser [12], Bhuiyan et al. [1], and Khodaei et al. [2]. This is an issue that is still under development due to the complexity of the combustion process, which requires various submodels for the thermo-chemical conversion of the biomass and sufficient computational resources for the simulation [9]. OpenFoam is a powerful open-source engineering tool, which has been successfully used in numerous applications. It has the advantages of being a free and open source, being constantly under development, and including solvers for many applications [13]. Despite these 
factors, there are relatively few works that use it to simulate the combustion of solid biomass. In order to guide researchers interested in the use of OpenFoam for this type of applications, this document provides a 2D simulation of combustion in a boiler fed with grape marc employing OpenFoam [14] [15] [16]. This is a simple model that predicts CO and $\mathrm{H}_{2} \mathrm{O}$ profiles of velocity and temperature over the freeboard.

\section{METHODOLOGY}

In this work, the combustion in a biomass boiler with dimensions $8 \mathrm{~m}$ wide and $15 \mathrm{~m}$ high in a $12.5 \mathrm{MWel}$ combined heat and power plant was simulated. The system was already analyzed in the work of Cordiner et al. [17] [18], but the novelty of our study lies in the simplicity of the model, which requires relatively few computational resources. The furnace operating conditions are presented in table 1. A squared mesh with a grid size of approximately 20 was used, the computational grid was done with the blockMesh utility (see figure 1). The characteristics of the biomass used are shown in table 2, which were also taken from the work of Cordiner et al. [18]. The volatilization kinetic parameters were taken from the work of Fiori [19].

Table 1. Furnace operating conditions [18].

\begin{tabular}{|c|c|}
\hline Condition & Value \\
\hline Biomass flow rate & $18,300 \mathrm{~kg} / \mathrm{h}$ \\
\hline Primary air flow rate & $53,750 \mathrm{~kg} / \mathrm{h}$ \\
\hline Secondary air flow rate & $53,750 \mathrm{~kg} / \mathrm{h}$ \\
\hline Secondary air nozzles diameter & $76 \mathrm{~mm}$ \\
\hline Secondary air nozzles number & $38(19+19)$ \\
\hline Primary air temperature & $170^{\circ} \mathrm{C}$ \\
\hline Secondary air temperature & $25^{\circ} \mathrm{C}$ \\
\hline
\end{tabular}

Table 2. Fuel characteristics [18].

\begin{tabular}{|c|c|}
\hline \multicolumn{1}{|c|}{ Property } & Value \\
\hline Volatile Fraction & $30 \%$ \\
$\mathrm{CO}$ & $80 \%$ \\
$\mathrm{CH}_{4}$ & $10 \%$ \\
$\mathrm{C}_{7} \mathrm{H}_{16}$ & $10 \%$ \\
\hline Solid Fraction & $20 \%$ \\
\hline Ashes & $30 \%$ \\
\hline C content & $52.1 \%$ \\
\hline Hcontent & $5.8 \%$ \\
\hline N content & $0.84 \%$ \\
\hline Scontent & $0.19 \%$ \\
\hline
\end{tabular}



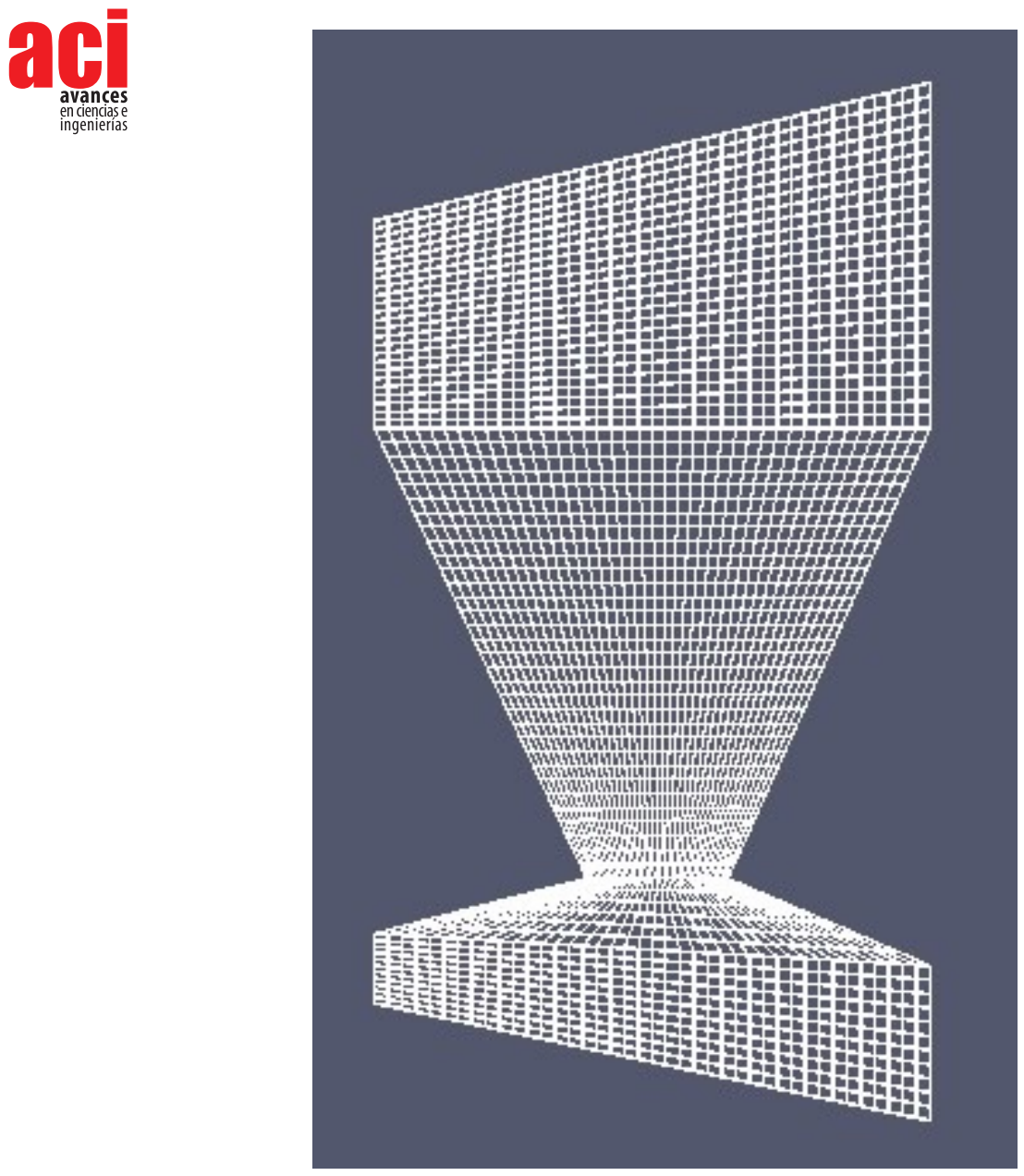

Figure 1. Computational Domain

The simulation was under the following main assumptions:

- The fuel (biomass) is supplied to the combustion chamber following a predefined path.

- Solid particles are not moved by gas action (drag and gravity forces are neglected) but gas phase movement is affected by bed particles.

- The Equations of continuity, energy and momentum of the gas are solved taking into account chemical reactions and interactions with the solid phase. 
An empirical 2D model implemented in OpenFoam was used, utilizing the coalChemistyFoam solver. To model the turbulence/chemistry interaction in the combustion process the $k-\varepsilon$ model and the Partially Stirred Reactor (PaSR) combustion model were employed, in the latter, the computational cells are divided into two zones, one in which all reactions occur and the other in which no reactions occur so that the composition changes due to the mass exchange with the reaction zone. The governing equations used in the gas phase are presented below:

- Continuity equation:

$$
\frac{\partial\left(\rho_{g}\right)}{\partial \mathrm{t}}+\nabla \cdot\left(\rho_{g} \mathbf{U}_{g}\right)=\mathrm{Sm}
$$

- Energy transpor equationt

$$
\frac{\partial\left(\rho_{g} h\right)}{\partial \mathrm{t}}+\frac{\partial\left(\rho_{g} \mathbf{K}\right)}{\partial \mathrm{t}}+\nabla \cdot\left(\rho_{g} \mathbf{U}_{g} h\right)+\nabla \cdot\left(\rho_{g} \mathbf{U}_{g} K\right)-\nabla \cdot\left(\alpha_{e f f} \nabla(h)\right)=-\nabla p+\rho_{g} \mathrm{Ug} \cdot \mathrm{g}+S_{h}
$$

- Momentum equation:

$$
\frac{\partial\left(\rho_{g} \mathbf{U}_{g}\right)}{\partial \mathrm{t}}+\nabla \cdot\left(\rho_{g} \mathbf{U}_{g} \mathbf{U}_{g}\right)-\nabla \cdot\left(\tau_{g}\right)-\nabla \cdot\left(\rho_{g} \mathbf{R}_{g}\right)=-\nabla p+\rho+\mathrm{g}+S_{\mathbf{U}}
$$

- Species transport equation:

$$
\frac{\partial\left(\rho_{g} Y_{i}\right)}{\partial \mathrm{t}}+\nabla \cdot\left(\rho_{g} \mathbf{U}_{g} \mathbf{Y}_{i}\right)-\nabla \cdot\left(D_{e f f} \nabla(\rho+Y 3)\right)=S_{i}
$$

$\mathrm{h}$ is the enthalpy, $\mathrm{S}$ is the source terms, $\mathrm{K}$ is kinetic energy, $\mathrm{Rg}$ is Ronald stress term, $Y_{i}$ is the mass fraction of the species, and aeff and Deff are the effective thermal and mass. The freeboard reaction mechanism used was proposed by Gómez et al. [20], which consists of the reactions summarized in table 3. The system was simulated in a computational cluster of the "Universidad Industrial de Santander", named GUANE, that consists in 16 ProLiant SL390s-G7 computing nodes such as shown in Table 4 [21] [22].

Table 3. Combustion reactions [21].

Homogeneous reactions

R1

$$
\mathrm{C}_{6} \mathrm{H}_{6} \stackrel{9}{+}{ }_{2} \mathrm{O}_{2} \rightarrow 6 \mathrm{CO}+3 \mathrm{H}_{2} \mathrm{O}
$$

$$
\mathrm{CH}_{4}+{ }_{2} \mathrm{O}_{2} \rightarrow \mathrm{CO}+2 \mathrm{H}_{2} \mathrm{O}
$$

R3

$$
\mathrm{H}_{2}+{ }_{2} \mathrm{O}_{2} \rightarrow \mathrm{H}_{2} \mathrm{O}
$$

R4

$$
\mathrm{CO}+{ }_{2} \mathrm{O}_{2} \rightarrow \mathrm{CO}_{2}
$$

R5

$$
\mathrm{H}_{2} \mathrm{O}+\mathrm{CO} \rightarrow \mathrm{CO}_{2}+\mathrm{H}_{2}
$$

R6

$$
\mathrm{CO}_{2}+\mathrm{H}_{2} \rightarrow \mathrm{H}_{2} \mathrm{O}+\mathrm{CO}
$$




\begin{tabular}{|c|c|c|c|}
\hline Setting Guane & A & B \\
Node type & SL390s & SL390s & SL390s \\
Number of nodes & 8 & 3 & 5 \\
Processor Intel & & & Xeon \\
Processor Model & Xeon & X5645 & E5640 \\
Processor by node (\#) & E5645 & 2 & 2 \\
Clock frequency (GHz) & 2 & 2.40 & 2.40 \\
Core/Processor (\#) & 2.40 & 6 & 4 \\
Thread/Core (\#) & 6 & 2 & 2 \\
GPUS Nvidia & 2 & Tesla & Tesla \\
GPUS Model & Tesla & M2075 & M2075 \\
GPUS by node (\#) & M2075 & 8 & 8 \\
Memory DDR (GB) & 8 & 104 & 104 \\
SAS disk (GB) & 104 & 200 & 200 \\
\hline
\end{tabular}

\section{RESULTS}

The furnace was simulated under steady state conditions, $\mathrm{CO}, \mathrm{H} 2 \mathrm{O}$ and velocity fields obtained are reported in figure 2. The results are similar to those obtained by[18], who simulated the same type of boiler. Although this model does not simulate NOx emissions, its value is that it achieves good results in a simple way with low computational resources. The calculated temperature closer to the outlet section equal to $1300 \mathrm{~K}$, which can be compared with the experimental one, that is equal to 1,270 $\pm 15 \mathrm{~K}$ [18]. Also, the CO, H2O and velocity values at the outlet of the chamber, evaluated in this study and taken from the literature [18], were compared; which can be seen in table 5. The difference between results is less than $6 \%$, which shows the capacity of the model to predict the behavior of the combustion of solid biomass. Therefore, the model developed is useful to study the feasibility of the use of new biomass fuels. 

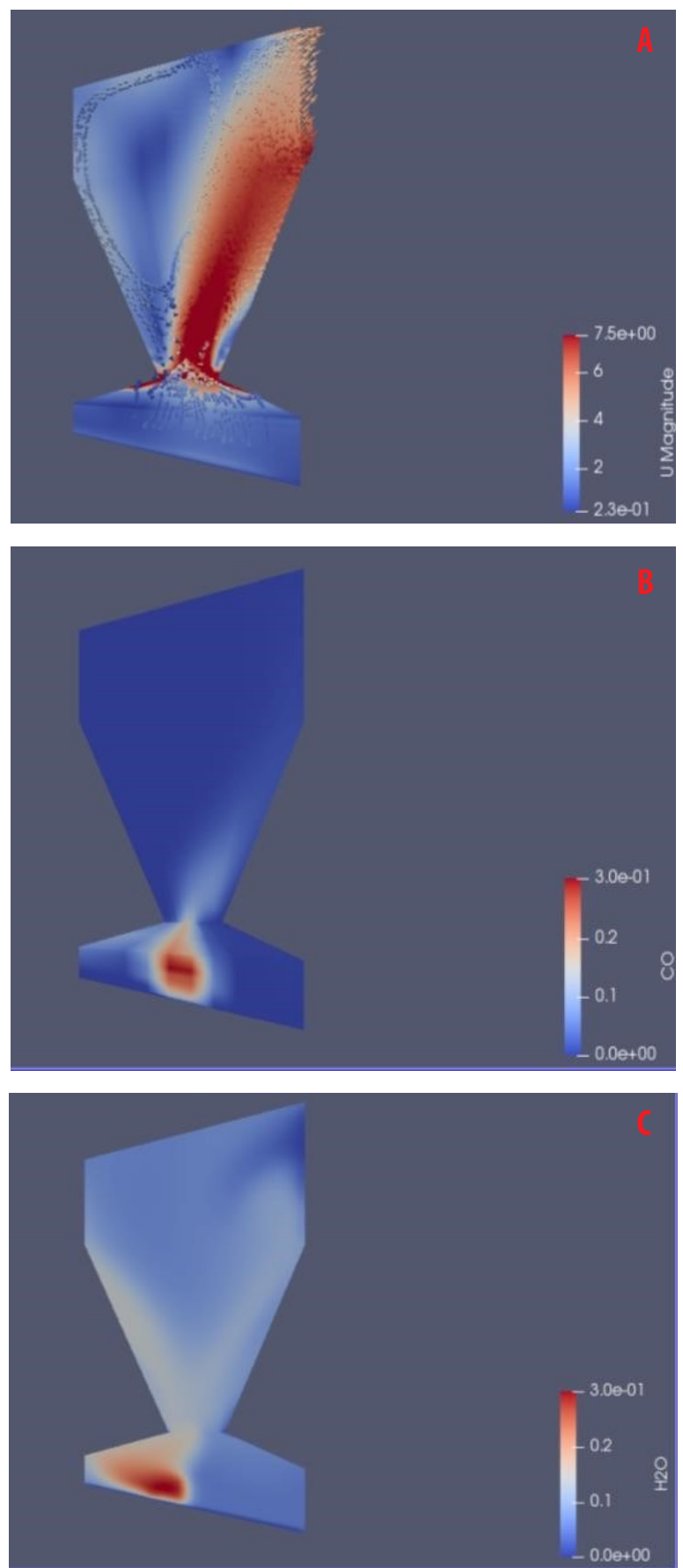

Figure 2. Simulation results. A) Velocity magnitude field [m/s]. B) CO mass fraction. C) H2O mass 
Table 5. Comparison between data obtained from the literature and data obtained in this work.

\begin{tabular}{|c|c|c|}
\hline \multicolumn{1}{|c|}{ Parameter } & Literature [18] & $\begin{array}{c}\text { This } \\
\text { study }\end{array}$ \\
\hline Velocity $[\mathrm{m} / \mathrm{s}]$ & 7.50 & 7.07 \\
\hline CO mass fraction & 0.00 & 0.00 \\
\hline H2O mass fraction & 0.13 & 0.10 \\
\hline
\end{tabular}

\section{CONCLUSION}

A 2D model for biomass furnace is reported in this paper, the model represents the evolution during thermal decomposition in the combustion chamber with a relatively low computational cost. The model is capable of predicting the $\mathrm{CO}$ and $\mathrm{H} 2 \mathrm{O}$ concentration and velocity, and temperature, profiles evolution over the freeboard. The results present an overall satisfactory behavior showing good agreement with literature data.

\section{ACKNOWLEDGMENT}

Agradecimientos a Colciencias, Ministerio de Educación Nacional, Ministerio de Industria, Comercio y Turismo e ICETEX, Convocatoria Ecosistema Científico - Colombia Científica. Fondo Francisco José de Caldas, Contrato RC-FP44842-212-2018.

\section{AUTHORS' CONTRIBUTIONS}

Gabriel Fernando García Sánchez: Conceptualization, Methodology, Writing- Original draft preparation; Jorge Luis Chacón Velasco: Supervision, Project administration; Yesid Javier Rueda Ordóñez: Supervision; David Alfredo Fuentes Díaz: Supervision; Jairo René Martínez Morales: Supervision, Project administration, Funding acquisition.

\section{CONFLICTS OF INTEREST}

The authors declare that they have no known competing financial interests or personal relationships that could have appeared to influence the work reported in this paper. 


\section{REFERENCES}

[1] Bhuiyan, A. A., Karim, Md. R., \& Naser, J. (2016). Chapter 11—Modeling of Solid and Bio-Fuel Combustion Technologies. En M. M. K. Khan \& N. M. S. Hassan (Eds.), Thermofluid Modeling for Energy Efficiency Applications (pp. 259-309). Academic Press. doi: https://doi.org/10.1016/B978-0-12-802397-

[2] Khodaei, H., Al-Abdeli, Y. M., Guzzomi, F., \& Yeoh, G. H. (2015). An overview of processes and considerations in the modelling of fixed-bed biomass combustion. Energy, 88, 946-972. doi: https://doi.org/10.1016/j.energy.2015.05.099

[3] Kanniche, M., Gros-Bonnivard, R., Jaud, P., Valle-Marcos, J., Amann, J.-M., \& Bouallou, C. (2010). Precombustion, post-combustion and oxy-combustion in thermal power plant for $\mathrm{CO}_{2}$ capture. Applied Thermal Engineering, 30(1), 53-62. doi: https://doi.org/10.1016/j.applthermaleng.2009.05.005

[4] Noussan, M., Cerino Abdin, G., Poggio, A., \& Roberto, R. (2014). Biomass-fired CHP and heat storage system simulations in existing district heating systems. Applied Thermal Engineering, 71(2), 729-735. doi: https://doi. org/10.1016/j.applthermaleng.2013.11.021

[5] Yin, C., Rosendahl, L. A., \& Kær, S. K. (2008). Grate-firing of biomass for heat and power production. Progress in Energy and Combustion Science, 34(6), 725-754. doi: https://doi.org/10.1016/j.pecs.2008.05.002

[6] Bhuiyan, A. A., \& Naser, J. (2015). CFD modelling of co-firing of biomass with coal under oxy-fuel combustion in a large-scale power plant. Fuel, 159, 150-168. doi: https://doi.org/10.1016/j.fuel.2015.06.058

[7] Szemmelveisz, K., Szücs, l., Palotás, Á. B., Winkler, L., \& Eddings, E. G. (2009). Examination of the combustion conditions of herbaceous biomass. Fuel Processing. Technology, 90(6), 839-847. doi: https://doi.org/10.1016/j. fuproc.2009.03.001

[8] Yang, Y. B., Sharifi, V. N., \& Swithenbank, J. (2004). Effect of air flow rate and fuel moisture on the burning behaviours of biomass and simulated municipal solid wastes in packed beds. Fuel, 83(11), 1553-1562.doi: https://doi. org/10.1016/j.fuel.2004.01.016

[9] Dernbecher, A., Dieguez-Alonso, A., Ortwein, A., \& Tabet, F. (2019). Review on modelling approaches based on computational fluid dynamics for biomass combustion systems. Biomass Conversion and Biorefinery, 9(1), 129-182. doi: https://doi.org/10.1007/s13399-019-00370-z

[10] García Sánchez, G. F., Chacón Velasco, J. L., \& Chaves Guerrero, A. (2013). Modelado de la combustión en motores Diésel: Revisión del estado del arte. REVISTA ION, 26(1). http://revistas.uis.edu.co/index.php/revistaion/article/ view/3506

[11] Versteeg, H., \& Malalasekera, W. (2007). An Introduction to Computational Fluid Dynamics: The Finite Volume Method (Edición: 2nd rev. ed). Prentice Hall.

[12] Karim, Md. R., \& Naser, J. (2014, diciembre 8). Progress in Numerical Modelling of Packed Bed Biomass Combustion. 19th Aust. Fluid Mech. Conf., Melbourne.

[13] Kasper, R. (2017). Particle Simulation with OpenFOAM ${ }^{\circledR}$. German OpenFoam User meetiNg 2017, Haus der Wissenschaften, Braunschweig, Germany. https://www.foamacademy.com/wpcontent/uploads/2016/11/ GOFUN2017_ParticleSimulations_slides.pdf

[14] Chen, G., Xiong, Q., Morris, P. J., Paterson, E. G., Sergeev, A., \& Wang, Y. C. (2014). OpenFOAM for computational fluid dynamics. Notices of the American Mathematical Society, 61(4), 354-363. doi: https://doi.org/10.1090/noti1095

[15] Jasak, H. (2009). OpenFOAM: Open source CFD in research and industry. International Journal of Naval Architecture and Ocean Engineering, 1(2), 89-94. doi: https://doi.org/10.2478/JNAOE-2013-0011

[16] Jasak, H., Jemcov, A., \& Kingdom, U. (2007). OpenFOAM: A C++ Library for Complex Physics Simulations. International Workshop on Coupled Methods in Numerical Dynamics, IUC, 1-20.

[17] Cordiner, S., Manni, A., Mulone, V., \& Rocco, V. (2014). A Detailed Study of a Multi-MW Biomass Combustor by Numerical Analysis: Evaluation of Fuel Characteristics Impact. Energy Procedia, 61, 751-755. doi: https://doi. org/10.1016/j.egypro.2014.11.958

[18] Cordiner, S., Mulone, V., Manni, A., \& Rocco, V. (2016). Biomass furnace study via 3D numerical modeling. International Journal of Numerical Methods for Heat \& Fluid Flow, 26(2), 515-533. doi: https://doi.org/10.1108/HFF-03-2015-0089 
[19] Fiori, L., Valbusa, M., Lorenzi, D., \& Fambri, L. (2012). Modeling of the devolatilization kinetics during pyrolysis of grape residues. Bioresource Technology, 103(1), 389-397. doi: https://doi.org/10.1016/j.biortech.2011.09.113

[20] Gómez, M. A., Porteiro, J., Patiño, D., \& Míguez, J. L. (2014). CFD modelling of thermal conversion and packed bed compaction in biomass combustion. Fuel, 117, 716-732. doi: https://doi.org/10.1016/j.fuel.2013.08.0786.00016-6

[21] García Henao, J. A., Martínez Abanunza, V. E., Alexandre Navaux, P. 0., \& Barrios Hernandez, C. J. (2015, agosto). EGPU for Monitoring Performance and Power Consumption on Multi-GPUs. Conference: Workshop de Processamento Paralelo e Distribuído, Porto Alegre. https://www.researchgate.net/publication/296699959_eGPU_for_ Monitoring_Performance_and_Power_Consumption_on_Multi-GPUs

[22] UIS, U. I. de S. (s. f.). Cluster Guane—Supercomputación y Cálculo Científico UIS. Recuperado 25 de agosto de 2020, de http://wiki.sc3.uis.edu.co/index.php/Cluster_Guane 